Témoigner Témoigner. Entre histoire et mémoire

Getuigen Revue pluridisciplinaire de la Fondation Auschwitz

$123 \mid 2016$

Traduire le témoignage

\title{
Theatre as Courtroom: The NSU Protocols in Freiburg
}

Tom Vanassche and Martin Hinze

\section{(2) OpenEdition}

\section{Journals}

Electronic version

URL: https://journals.openedition.org/temoigner/5075

DOI: 10.4000/temoigner.5075

ISSN: 2506-6390

Publisher:

Éditions du Centre d'études et de documentation Mémoire d'Auschwitz, Éditions Kimé

Printed version

Date of publication: 1 October 2016

Number of pages: $22-26$

ISBN: 987 2-9600926-4-6

ISSN: 2031-4183

Electronic reference

Tom Vanassche and Martin Hinze, "Theatre as Courtroom: The NSU Protocols in Freiburg", Témoigner. Entre histoire et mémoire [Online], 123 | 2016, Online since 02 November 2021, connection on 04 November 2021. URL: http://journals.openedition.org/temoigner/5075 ; DOI: https://doi.org/10.4000/ temoigner.5075 
•. ence anticipating Zschäpe's testimony "disrupt" the play, making the other actors become barely audible This dis ruption can be understood as a critique of the nedia's coverage or the events, and of their preoceupy Zsempe. As alre sty ingothetical - declaration by Zschape. As alre sy in a dised, her real-life declafocus of the play is on Zschäpe's defent. Another focus of the play is on Zschape's de rener her the apuin herself has found a fourth laver. What the accused herstor follows is a constant bickering amongst the lawyer Nebenkinger and ene the trical pons are pushed to the background. The theatrical polemics and the constant disruptions ultiillo thirty months of cynicism and sensation.

LITERARY AND THEATRICAL TRADITIONS

Apart from the fact that the Protocols expose insttutional racism, it is rewarding to put the performance in a diachronic perspective. After all, by its functioning motion the tre as a means to chane society, but, notion of theatre as a means to change society, but, fictionlized account of the events. As such, The NSU Protocols show sont of the events. As sulte The NSU Weiss's Die En some remarkable parallels to Peter Weiss's Die Enittlung (The Investigation, 1965). Die Ermittlung is a literary representation of the Frankfurt Auschwitz tral, focussing not just on the Nazi crimes, but also on the ine rimed to break a majs in them. West German socisty and provoked a pajel troo the tria of capitalism. In a way, The NSU Pro. tocols also stage a parallel trial, this time of the police, the Verfassungsschutz, of the disrespectfully cynica the the tre makers the elioments explain why the TSU, whose members were known by the aur why ince the 1990s, could operate with impunity forities since the 1990s, could operate with impunity for such long time.

Both texts share the use of the Brechtian Verfremaungseffeht (alienation effect), albeit in differ-

(2) "[Die Poesie] soll das Herz treffen, weil sie aus dem Herzen flof, und (2) "IDie Poesie] soll das Herz treffen, weil sie aus dem Herrzen flofo, und
nicht auf den Staatsbürger im Menschen, sondern auf den Menschen in dem
Staatsburger zielen." (Schiller 1793, 514)

deliberately refuses any resolution: the play ends with rhetorical victory for the defendants, whereas in reality most were convicted and sentenced to prison. The use of co alienation effects in The NSU Protocols is a bit more firstly, it in placontans fisty, it incorporates anti-mimetic elements. all are perfor cothes. The the play's in alinently mimetic ambition of actin with the play's inherently minetic anbition of acting as a procol of a real-life trial, even though selection and to it as is it to all forms of documentary ant. It serent to it, as is it to all forms of documentary art. It seems. dowe the play foduces the NSU case to thels and costumes, the play reduces the NSU case to the linguistic essence or testimonial, interrogative, and investigative utterances-butalso their opposite

The constant switching of roles creates a second lienation effect, since it increases the tension in the playhouse and demands the audience's relentles attention, while hindering identification with the witnesses or perpetrators. By contrast, longer reading sequences are strategically employed to emphasize the consequences of the NSU's violence and to enable the build-up of an emotional rapport to the victims. the build-up of an enotional rapport to the victims. . prover fictionalize the eye-witness accounts in order to provoke an enotional response, whereas Weiss added 列 esque fashion in order to illustrate the hopelessness Another interestingobject of

Another interesting object of comparison, besides die Ermittlung, are the staged trials in the arts of the eariy Soviot Un (ron of the 1920s. At the time, fictional agitation trials (russ. agitsudy) were a popular theatrical genre in the countryside and cities alke. The defendent procutor, defender judge a defendant, prosecutor, defender,judge and witnesses The performances were at times so convincing that even newspapers took then for real and could not distinguish actual from staged trials. Given the many illusion illusion of a real trial. Rather, the theatre stage becomes an extension of he orginal corty Protocols and the early Soviet agitation trials have in informing at the same time.

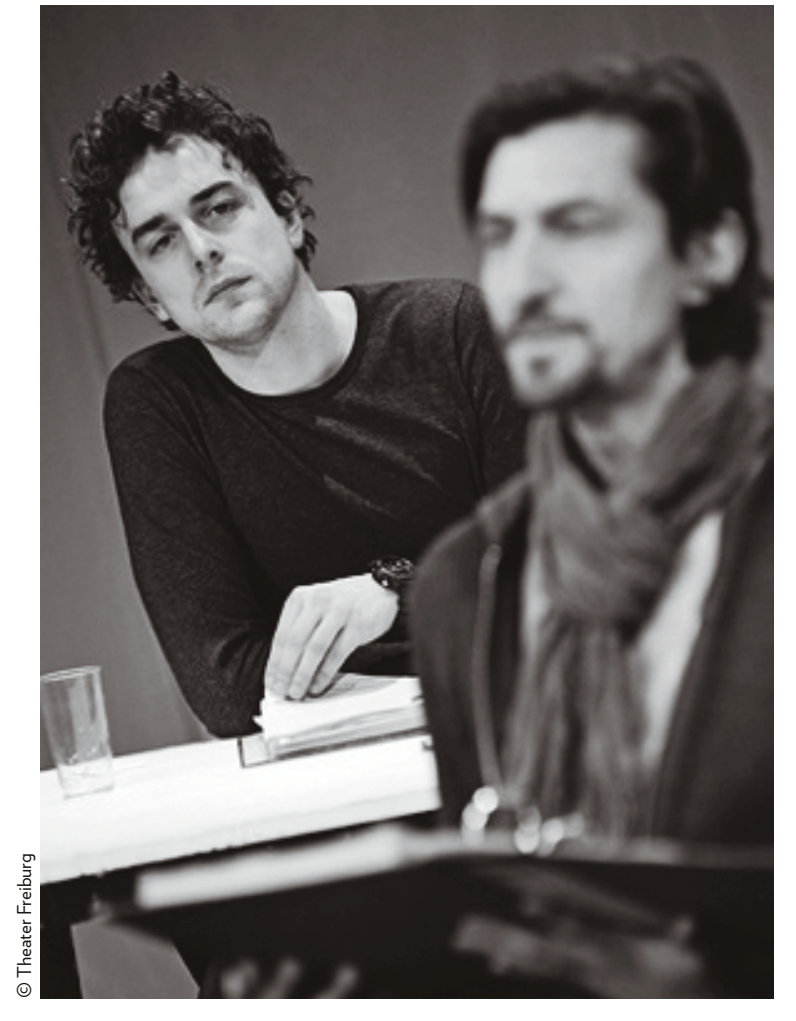

The NSU Protocols also show similarities with the concept of factography, which emerged in the Soviet Union in the late 1920s. This avant-garde programme tried to reunite art and life by devoting art to empiric reality rather than fiction. One of its champions was ber of the artistic a law school gratuate and a memPerhaps infuect by the popularty of the agitation Perhaps infurition trials, he integrated people's courts against alleged his "literature of fact" (russ. Literatura fahta). Triat scenes and juridica (n scenes and juridical procedures had already been interis interrogations Dostoyevshy's Crimeand Punishment the en The Brothers Karamazov demazov towards

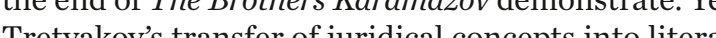
Tretyak s transfer of juridical concepts into literaWheres in the past the author appeared in his literWhereas in the past, the author appeared in his literjudge, he can now also be the accused. The avant-garde approach strives to render the boundary between art and justice porous (Strätling 2011, 311-313).

Strätling's historical observations are relevant for he artistic concept of the Freiburg NSU Protocis as well, since the "autho" of this piece is a collective of ell, since the "author" of this piece is a collective of By sta.ing testimies from a still ongong tial, By staging testimonies from a still ongoing thal, the shape public opinion. As in the factographic project, the Protocols insist diction an an (3) ach percion, we like a per and feels like a part ofit, since usually only few visitors differ Visito do not on Vistors do not only seek cultural delight, but also they the NSU affair has been h the by the aung the way They seek a different mand of They seek a different medium for information and $\bullet \bullet$

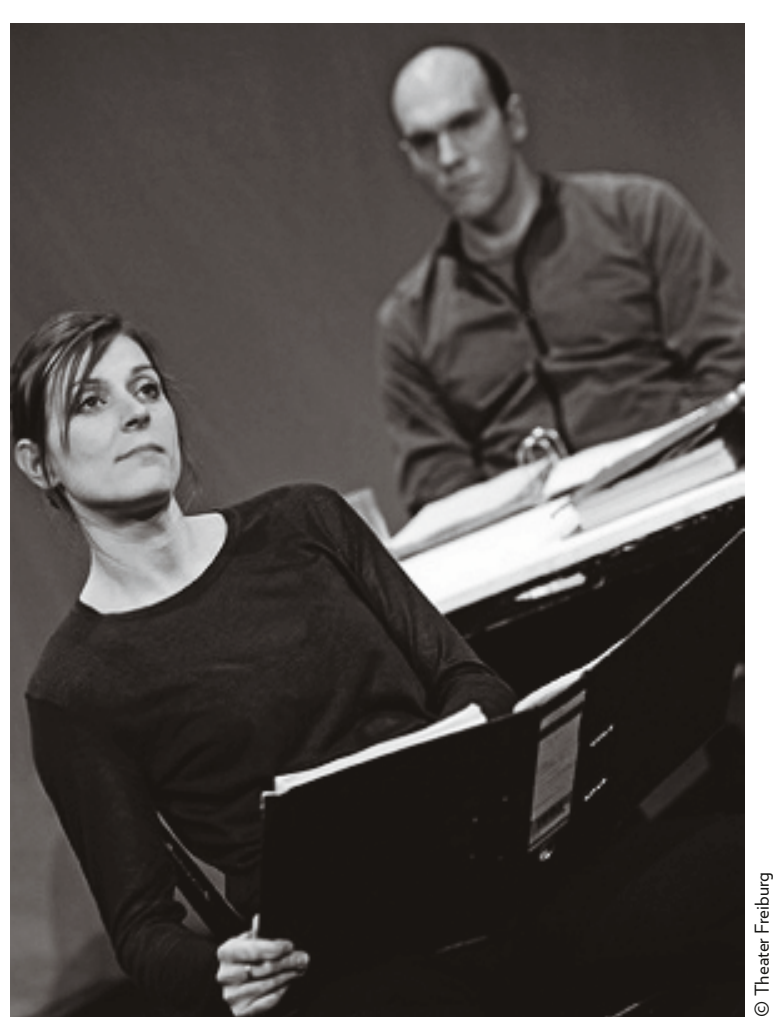


- communication. As Brecht and Tretyakov both stipulated around 1930, the audience has become a vital and necessary part of the performance. The collective process of exchange during and after the performance contributes to every visitor's judgement about the staged trial.

This is theatre with a mission, achieved in a collaborative way and based on a division of labour: in situ at the trials in Munich, reporters from involved newspapers like the Frankfurter Rundschau and Süddeutsche Zeitung collect factual material. In Freiburg, the theatre staff transforms news facts into a performance. Afterwards, specialists (journalists and lawyers), cast, crew, and audience discuss the topic together. As one participant noted, the factual material of speeches and counter-speeches uttered in the real-world courtroom already is a product of collective interaction no solitary mind could imagine. It is also in this regard that the Protocols bear similarities with the collective work that was promoted by factography.

\section{CONCLUSION}

Let's return to the performance's opening: is Hitler really dead? The question may seem provocative but should not be read in this way. The "NS" in NSU point to more than an extreme-right ideological position; they reveal an overall xenophobic mind-set in which antisemitism features prominently. ${ }^{3}$ The NSU Protocols offer a different perspective on Germany's reunification in 1990, which arguably led to a practical power vacuum in the former GDR, and enabled the socialization of German youths in a far-right scene. The state did not enough to prevent the radicalization of these people, who ultimately founded a violent neoNazi movement.

The Protocols thus expose institutional racism, and fit in a literary and theatrical tradition that seeks civic participation. Indeed, by insisting on textual rather than dramatic mimesis and using this mimesis to steer sympathy and empathy towards the victims of political violence, the performance ultimately makes an urgent appeal to civil society: to detect and acknowledge racism and other forms of discrimination, and to

(3) Its members may not have killed any Jews, but they did develop a neo-Nazi version of Monopoly: Pogromly, where one does not buy train stations but concentration camps. Chance and Community Chest cards have been replaced by SS and SA cards, (rhetorically) rewarding anti-Semitic behaviour and sanctioning acts of sympathy or kindness towards Jews. fight them. This civil courage (Zivilcourage) ought to be the true Verfassungsschutz (which would translate as "Agency for the Protection of the Constitution"), since the agency has proven incapable of protecting the German constitution and its first article stipulating the inviolability of human dignity.

Yet if anything, the history of the NSU ought to be a warning to other European countries. Germany has often been heralded as the country par excellence that has critically and extensively assessed its own violent past. The fact that these murders were committed in Germany and remained unsolved for such a long time has put the country's much-praised self-critical attitude to question.

Tom Vanassche

Albert-Ludwigs-Universität Freiburg/Ghent University

Martin Hinze

Albert-Ludwigs-Universität Freiburg

\section{Learn more}

Die NSU-Protokolle: Das erste Prozessjahr, 29 October 2015

Die NSU-Protokolle: Das zweite Prozessjahr, 23 January 2016

Die NSU-Protokolle: Das dritte Prozessjahr, 11 February 2016

Theater Freiburg

\section{Works cited}

Fore, Devin, 'Die Emergenz der sowjetischen Faktografie', Deutsche Vierteljahrsschrift für Literaturwissenschaft und Geistesgeschichtte DVjs 89(3), 2015, 376-403.

Schiller, Friedrich, 'Über das Pathetische' [1793], in Gerhard Fricke \& Herbert G. Göpfert (eds.), Sämtliche Werke, vol. 5, Munich: Hansen, 1993, 512-537.

Strätling, Susanne, 'Wort und Tat. Sergej Tretjakovs juridischer Pakt mit der Literatur, in Csongor Lörincz (ed.), Ereignis Literatur. Institutionelle Dispositive der Performativität von Texten, Bielefeld, 2011, 307-330.

$\rightarrow$ Tretyakov, Sergej, 'Prodolženie sleduet' (To be continued), Novyj LEF 2(12), 1928, 1-3.

$\diamond$ Žirnov, Evgenij, 'Samyj inscenirovannyj sud v mire' (The most staged court in the world), Kommersant, 14 April 2008, http://www.kommersant.ru/doc/879057 (accessed 16 March 2016) 